\title{
Effect of Internal Control System on Employee Performance of Small-Scale Manufacturing Enterprises in Ondo State, Nigeria
}

\author{
Adedeji Abosede Olufunmilayo \\ Department of Business Administration, Federal University of Technology, Akure, Nigeria
}

Tel: 234-803-403-3814 E-mail: aoadedejiyahoo.com

Olubodun Opeyemi Hannah

Department of Project Management Technology, Federal University of Technology, Nigeria

Tel: 234- 803-518-7941Ｅ-mail: opebodun@gmail.com

Received: April 16, 2018 Accepted: June 2, 2018 Published: July 4, 2018

doi: 10.5296/hrr.v2i1.13016 URL: https://doi.org/10.5296/hrr.v2i1.13016

\begin{abstract}
The study was aimed at examining the influence of internal control system on employee performance. The population was 4,500 enterprises registered with the Nigerian Association of Small Scale Industrialists (NASSI) in Ondo State, out of which 195 randomly selected manufacturing enterprises formed the sample of the study. Primary data were collected and analysed using percentages and mean. The hypothesised model structure was analysed using ordered logistic regression with the significant level at $p=0.05$. The Pseudo $R^{2}$ of 0.0353 indicated that the significant independent variables of the model accounted for $3.53 \%$ variation in the employee performance. Other factors which did not form part of the variables of the model accounted for the remaining variation. The study revealed that control environment and monitoring have significant effect on employee performance. The study concluded that internal control system significantly have influence on employee performance of small scale manufacturing enterprises in Ondo State, Nigeria. It was recommended that small scale manufacturing enterprises should give priority to be implementation of internal control system components since they influence employee performance and ultimately organisational performance.
\end{abstract}


Keywords: Internal control system, Employee performance, Small-scale, Manufacturing, Enterprises

\section{Introduction}

Employee performance can be called the life wire of an organisation, in that the good performance of employees may turn an unknown small business to a market leader in its industrial sector. Dapper (2013) expressed organisational performance as cost efficiency, employee productivity and organisational profitability. An organisation is incomplete without its employees whose productivity adds value to the system and often determines its profitability. The importance of employee performance to the organisation cannot be overemphasised since employees are the human capital of organisations and their performance is a key indicator of an organisation to achieve its goals (Aboazoum, Nimram, \& Musadieq, 2015). Organisations strive to attract, acquire, utilise and retain competent employees for competitive advantage. The performance of employees of small businesses tends to depend largely on their control environment. This is because, the performance that is guided by clearly established lines of authority and responsibility plus recruitment and selection of competent staff will be measurable in an environment where there is control and monitoring. It follows that compliance with organisational internal control system ensures that employee performance is done in line with policies and procedures. Things may not be done accordingly in small manufacturing enterprises based on the assumption that they have few resources to manage but every resource is valuable.

According to Noe, Hollenbeck, Gerhart and Wright (2011), employee performance measures are related to the goals of the organisation and may be based on managing organisational objective, employee's behaviours and apparent attitudes or results such as sales, productivity and costs. They asserted that it is the organisation that decides employee's key performance areas to be appraised and the methods of measurement and performance measures.

Braun (2016) stated that a small business is open to different fraudulent activities, some of which are employee related, such as embezzlement and workers' crime. Internal control is important and ought not to be overlooked no matter the size of a business concern. According to Oseifuah and Gyekye (2013), majority of business failures has been attributed to lack of internal control system. Studies have also shown that most new businesses become moribund few years after establishment as a result of poor internal control systems (Kamau 2014). Adagye, (2015) revealed that weak internal control in small businesses affects the effectiveness of their employees in the achievement of organisational goals and objectives. Small businesses either have weak control system or no control system at all (Campbell \& Hartcher, 2003). One of the arguments put forward for the absence of effective and efficient internal control system in small businesses is its costly implementation (Modisane, 2013). While internal control system is cost bearing, it may protect the assets and other resources of the organisation and may result in organisational efficiency and effectiveness. All functions are supposed to be carried out in line with organisational policies and procedures in order to ensure industrial harmony and a fraud free environment. For example, segregation of duty is a difficult task to achieve wherever there is poor control system or when duties are not efficiently and effectively segregated, overlap of functions may result in asset loss due to lack 
of accountability. Every process/task is expected to have an owner; for accountability and appraisal purposes.

Perhaps little attention is being paid to the influence of internal control system on employee performance of small businesses, making it look as if small businesses operate in total disregard to policies and leading to their mass failures. When internal control is studied, emphasis is mostly on its effect on profitability, financial standing or organisational performance. The relationship between internal control and employee performance tends to be overlooked or underrated in research. This ought not to be since it is the employees at different levels of management who drive the business. Recruiting competent and trainable staff is internal control related. The issue of employees should not be handled with levity because they can harm the business through their partial or non-adherence to policy guidelines on some or all aspects of the organisation. Internal control and employee performance should come to the fore since grooming small businesses to take the centre stage in driving the Nigerian economy is the focus of governments at all levels (Olatunji, 2013). Since small businesses including manufacturing enterprises are not too small for effective internal controls, they can enforce certain controls that are very effective and impact employee performance. According to Stevenson (2006), manufacturing organisations have become greatly competitive to the extent that customer satisfaction cannot be achieved without production, planning and control. The control aspect provides policies and procedures guiding the accomplishment of organisational goals with minimum cost outlay and prevention of avoidable wastage. This study was conducted to empirically examine the effect of internal control system on employee performance and add to the body of knowledge on internal control and employee performance of small scale manufacturing enterprises in Ondo State, Nigeria.

\section{Literature Review}

\subsection{Conceptual Review}

Conceptually, employee performance entails the performance of tasks in adherence to the specified job description (Rashid, Shireen, Rab, Anam, Hafiza, \& Somia, 2013). Important as employee performance is, many factors have been found to influence it, such as manager's attitude, organizational culture, personal problems, job content, motivational packages and financial reward (Muogbo, 2013, Dunmade \& Aderibigbe, 2017). The effect of internal control system on employee performance of small scale manufacturing enterprises is different from most studies that abound in literature hence it forms the focus of this study. Employees are humans with emotions, needs and wants that can impact their behaviours, attitudes and actions as far as being compliant to policy is concerned and ultimately their performance at work.

The concept of internal control system covers all the rules, policies and procedures which their implementation ensures that organisational operations, financial reports and activities are to a reasonable extent safe, sound and within the ambits of extant laws and regulations (The American Institute of Certified Public Accountants - AICPA, 2007). The Committee of Sponsoring Organizations of the Treadway Commission (COSO), (1992) added that internal control is effected by an entity's board of directors, management, and other personnel. It means that employees involvement at all levels of management is critical to the success of the 
implementation of internal control system in an organisation. The body notes that internal control can provide reasonable, not absolute assurance that the objectives of an organisation will be met, perhaps putting the human nature into consideration. In fact, human resource practices and the deployment of professionals are aspects of internal control system (Mwakimasinde, Odhiambo \& John, 2014). Employees must be competent to add value to the organisation and where they are incompetent there will be service failure and customer dissatisfaction.

Ndifon and Patrick (2014) viewed internal controls as the actions undertaken by an entity in order to accomplish its vision and missions using a set of policies and procedures that prevent wastages and fraudulent activities. According to COSO (1994) framework, internal control system is made up of five essential and interrelated parts. Their presence in the organisation constitute control effectiveness. They include: 1) a conducive control environment, 2) organising risk assessment, 3) availability of an effective and efficient information and communication, 4) provision and implementation of policies and procedures, and 5) continuous monitoring of control-related policies and procedures for feedback. All the parts must be available in an organisation that has good internal control system in order to be safe and sound operationally. Judging from the high rate at which small scale manufacturing enterprises become moribund in Nigeria, this study was conducted in Ondo State.

\subsection{Theoretical Framework}

Employee performance has been generating interest for long due to the fact that employees put other resources of production to work. They also plan and carry out other managerial functions in order to achieve predetermined goals and objectives of the organisation. Employee performance may be anchored on motivational theories that motivated employees will perform their duties well through adherence to policies, procedures, rules and regulations as embedded in the organisation's internal control system. Douglas McGregor's (1960) Theory X and Y becomes relevant. For McGregor, the theory can be looked at as two distinct elements. Relying on a combination of both theories may be suitable for production efficiency, bearing in mind that there are individual differences and workforce diversity. Employees are expected to leverage on internal controls to ensure effective performance of tasks with adherence to control procedures.

Theory X average workforce are more efficient under "hands-on" approach to management and can benefit a work place that is more suited towards an assembly line or physical labour type of duty (Sager, 2008; Sorenson, 2015). In other words, such employees may not follow control procedures and activities in an organised establishment, which may be detrimental to the organisation. Theory Y employees on the other hand, are viewed as valuable human capital who coordinate and run the internal dynamics of the organisation well (Avolio, 2007). Such employees are energised by the challenges of the job and aspire to improve the quality of their job and the products (Wallgren, 2013). They work with minimal supervision and are accountable for their actions and inactions (Sager, 2008). It follows that both control system breakers as well as employees that adhere to policies and procedures abound in the workplace, but being motivated by different factors. Viewed from these two perspectives, internal control system and employee performance is based on the theory as its theoretical framework. 


\subsection{Empirical Framework}

Internal control and organisational performance has been studied by various researchers spanning different countries and locations. For example, Goodwin-Stewart and Kent (2006), found that only one-third of the sampled companies in Australia use internal audit and that there was weak support for an association between the use of internal audit and strong corporate management. This means that internal audit and corporate management are not strongly related. It could mean that corporate management depended on other factors, perhaps external control system.

Arindam (2016) gave sixteen factors that lead to poor performance at workplace and four of the factors are directly related to internal control system. The factors are: 1) poor leadership from the top management which affects followership and their output; 2) lack of role clarity which can create friction among workers and lead to disagreements; 3) lack of clarity about accountability when functions are not clearly apportioned among members of the team. There should be clearly defined roles, authority and accountability; and 4) lack of transparency when the flow of communication about decisions is ineffective, thereby encouraging rumour mongering among the workforce. These can be detrimental to organisational achievement of goals. The studies were not solely directed at employee performance. Perhaps, the researcher was more concerned about other factors of production other than the workforce who will formulate, implement and appraise the control system.

Ewa and Udoayang (2012) conducted a study on the impact of internal control design on banks' ability to investigate staff fraud, staff life style and fraud detection in Nigeria. The sample of the study consists of 13 banks and the data collected were analysed using percentages and ratios. The result of the study showed that internal control design had influence on staff attitude towards fraud and that a strong internal control system prevents staff fraud while a weak one provides avenues for staff to commit fraud. It follows that where resources are well controlled, employees would find it difficult to cheat, steal of falsify reports except if there was staff collusion involving highly placed employees.

Linval (2012) examined the influence of internal control on the operations of small restaurants in the United States of America. 270 restaurants were selected through random sampling technique. The data collected were analysed using exploratory data analysis, including descriptive statistics and multiple regression. The findings showed that internal control has positive effects on small restaurants survivability and profitability. The result further showed that internal control structures were adequate to protect assets and that financial information was objective and reliable.

Tumisang and Swami (2014) assessed the impact of internal controls on managing resources of small businesses in Botswana. The study examined the availability or otherwise of internal controls in small businesses and the cost of their implementation. Data were obtained from 52 randomly selected respondents. Using descriptive statistics for data analysis, the researchers found that most businesses have internal controls that are moderately expensive to establish and that the employees can get the knowledge on internal controls through in-service training, education, meetings and briefings. Internal controls implementation requires training and retraining of employees who implement the control processes. 
Mwakimasinde et al. (2014) studied the effects of internal control systems on financial performance of sugarcane outgrower companies in Kenya. The study adopted a descriptive correlation survey design and all the nine sugarcane outgrower companies were studied. The study found a positive significant effect of internal control system on the financial performance of the companies $\left(\mathrm{R}=0.682, \mathrm{R}^{2}=0.428\right)$. They concluded that internal control system helps increase performance of sugarcane outgrowers in Kenya.

The reviewed literature shows that many researchers have studied the relationship between internal controls and different aspects of performance of small manufacturing businesses but few are on employee performance. The focus of this study is on internal control and employee performance.

\section{Methodology}

\subsection{Sampling}

The population of the study comprised all the 4,500 registered members of the Nigerian Association of Small Scale Industrialists (NASSI), Ondo State Chapter. The outfits are located in the three senatorial districts of the state namely Ondo North, Ondo South and Ondo Central. Using Yamane's Statistical Distribution Formula (1967), a sample size of 195 randomly selected owners of manufacturing enterprises formed the respondents.

\subsection{Data Collection}

A set of self designed questionnaire with Likert-type rating scale range of large extent (5) as highest rating to low extent as lowest range (1) was the instrument used for the collection of primary data. The questionnaire comprised a section seeking information on the demographic variables of the respondents and another section containing statements eliciting responses on internal control and employee performance in the organisations. The copies of questionnaire were distributed and collected by the researchers and trained research assistants. All the distributed copies were collected because the respondents had a secretariat where members of the association were meeting monthly. It was not difficult to follow up on the respondents either at the association's secretariat or their factories which are located within the state. The collection rate was 100 percent, that is; all the 195 copies were retrieved.

\subsection{Data Analysis}

The data collected were analysed using descriptive statistics such as frequency and mean while ordered logistic regression analysis was the inferential statistics used to test hypothesised model structure on the effect of internal control system and employee performance of the selected manufacturing outfits.

\subsection{Model Specification and Measurement of Variables}

The ordered logistic regression was used in this study because it is an ordinal regression model for ordinal dependent variables. It is an aspect of the logistic regression model that applies to dichotomous dependent variables, which permits more than two (ordered) response categories. The model was specified as follows:

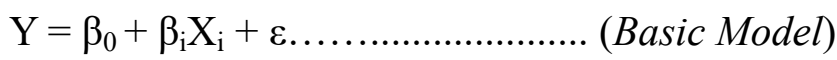

Where: $Y=$ The perceived employee performance

Given that the respondents' answers include "poor", "fair", "good", and "very good", with $p_{1}$, 
$p_{2}, p_{3}, p_{4}$, respectively. Then the logarithms of the odds of answering in certain ways are:

Poor employee performance $=\log \frac{P_{1}}{P_{3} P_{3} P_{4}}=0$

Poor or fair employee performance $=\log \frac{B_{*} E_{k}}{B_{2} E_{4}}=1$

Poor or fair or good employee performance $=\log \frac{P_{4} P_{k} P_{9}}{P_{4}}=2$

$\beta_{0}=$ Constant

$\mathrm{X}_{\mathrm{i}}=$ the matrix of independent/explanatory variables,

$\beta_{\mathrm{i}}=$ the regression coefficients,

$\varepsilon=$ the error term.

$\mathrm{Y}$ is the employee performance which is dependent on the explanatory variables $\mathrm{X}_{1}, \mathrm{X}_{2}$, $X_{3, \ldots} X_{n} \varepsilon$ that is, how much change in employee performance is accounted for by each of the explanatory variables and how much is unexplained as measured by the error term $\varepsilon$. The regression model was implicitly specified as:

$\mathrm{Y}=\mathrm{f}\left(\mathrm{x}_{1}, \mathrm{x}_{2}, \mathrm{x}_{3}, \mathrm{x}_{4}, \mathrm{x}_{\mathrm{n},} \varepsilon\right)$.

More specifically, the variables specifications were as follows:

$\mathrm{Y}=$ Employee Performance, $\mathrm{x}_{1}=$ Control Environment, $\mathrm{x}_{2}=$ Risk Assessment, $\mathrm{x}_{3}=$ Control Activities, $\mathrm{x}_{4}=$ Information and Communication, $\mathrm{x}_{5}=$ Monitoring, $\varepsilon=$ the error term.

The variables were viewed as significant at $95 \%$ confidence level whereby, variables with a ' $\mathrm{p}$ ' value of 0.05 and below were considered significant and the ones with 'p' values above 0.05 were considered insignificant.

\section{Results}

\subsection{Components of Internal Control System Used in Small Scale Manufacturing Enterprises}

The result of the study as presented in Table 1 revealed that all the five components of internal control system were implemented in the selected manufacturing enterprises. The breakdown showed that control environment is implemented to a large extent, risk assessment to a large extent, control activities to a large extent, information and communication to a moderate extent and monitoring to a moderate extent.

Table 1 . The components of internal control system of small scale manufacturing enterprises

\begin{tabular}{lll}
\hline The components & Grand mean & Decision \\
\hline Control Environment & 4.5 & Large extent \\
Risk Assessment & 4.6 & Large extent \\
Control Activities & 4.6 & Large extent \\
Information and Communication & 2.8 & Moderate extent \\
\hline
\end{tabular}


Moderate extent

\subsection{Perceived Employee Performance of the Sampled Small Scale Manufacturing Enterprises}

Perceived employee performance is the dependent variable and has four components which are; employees complete their work timely, employees do their work properly, employees are punctual to work, and employees are loyal to the organization. Table 2 explains the result of the perceived employee performance in the selected small scale manufacturing enterprises.

Table 2. Employee performance of the sampled small scale manufacturing enterprises

\begin{tabular}{|c|c|c|c|c|c|c|c|c|c|}
\hline \multirow{2}{*}{ Personnel Performance } & \multicolumn{5}{|c|}{ Options } & \multirow{2}{*}{$\mathrm{F}$} & \multirow{2}{*}{$\Sigma f \mathrm{x}$} & \multirow{2}{*}{$\bar{x}$} & \multirow{2}{*}{ Deci-sion } \\
\hline & VGE & GE & M & LE & $\mathrm{NE}$ & & & & \\
\hline $\begin{array}{l}\text { Employees complete their work } \\
\text { timely }\end{array}$ & 85 & 101 & 9 & - & - & 195 & 856 & 4.4 & GE \\
\hline Employees do their work properly & 16 & 24 & 32 & 63 & 53 & 188 & 451 & 2.4 & LE \\
\hline Employees are punctual to work & 22 & 23 & 26 & 12 & 106 & 189 & 410 & 2.1 & LE \\
\hline $\begin{array}{l}\text { Employees are loyal to the } \\
\text { organization }\end{array}$ & 6 & 24 & 40 & 71 & 54 & 195 & 442 & 2.3 & LE \\
\hline
\end{tabular}

Note: VGE=Very great extent $(\bar{X} \geq 4.5), \mathrm{GE}=$ great extent $(3.5 \leq \bar{X} \leq 4.49)$,

$\mathrm{ME}=$ Moderate extent( $2.5 \leq \bar{X} \leq 3.49), \mathrm{LE}=$ Little extent $(1.5 \leq \bar{X} \leq 2.49)$,

$\mathrm{NE}=$ No extent $(0 \leq \bar{X} \leq 1.49)$.

\subsection{Effect of Internal Control System on Employee Performance of Small Scale Manufacturing Enterprises}

The result of the ordered logistic regression as shown in Table 4 revealed that the components of internal system that had a positive significant effect on the employee performance include control environment $(p=0.03)$ and monitoring $(p=0.07)$. This is an indication that increase in the quality of the control environment and monitoring will increase employee performance, while a decrease in the quality of the control environment and monitoring will decrease the employee performance in the enterprises. The Pseudo $\mathrm{R}^{2}$ of 0.0353 is an indication that the significant independent variables of the model accounted for $3.53 \%$ variation in the employee performance. This further revealed that internal control system has significant effect on employee performance.

\subsection{Validation of the Ordered Logistic Regression Equation}

The ordered logistic equation shows that a unit change in control environment $\left(\mathrm{x}_{1}\right)$ will cause a positive change of $61.78 \%$ in the employee performance, also a unit change in risk assessment $\left(\mathrm{x}_{2}\right)$ will cause a negative change of $27.21 \%$ in the employee performance, a unit 
change in control activities $\left(\mathrm{x}_{3}\right)$ will cause a negative change of $5.88 \%$ in the employee performance, a unit change in information and communication $\left(\mathrm{x}_{4}\right)$ will cause a positive change of $5.8 \%$ in the employee performance, and a unit change in monitoring $\left(\mathrm{x}_{5}\right)$ will cause a positive change of $47.89 \%$ in the perceived employee performance. Internal control system has a significant effect on employee performance of small scale manufacturing enterprises in Ondo State.

$(\mathrm{Y}$ : Employee Performance $)=0.6178474 \mathrm{x}_{1}-0.2721134 \mathrm{x}_{2}-0.0588757 \mathrm{x}_{3}+0.0587114 \mathrm{x}_{4}+$ $0.4789871 \mathrm{x}_{5}+\mathcal{E}=0.0353$

Keys: $\mathrm{x}_{1}=$ Control Environment, $\mathrm{x}_{2}=$ Risk Assessment, $\mathrm{x}_{3}=$ Control Activities, $\mathrm{x}_{4}=$ Information and Communication, $\mathrm{x}_{5}=$ Monitoring.

Table 4. Ordered logistic regression output

Ordered logistic regression

Number of observations $=195$

$\begin{array}{ll}\text { LR Chi }(2) & =14.00 \\ \text { Prob }>\text { Chi2 } & =0.0156 \\ \text { Pseudo } R^{2} & =0.0353\end{array}$

Log likelihood $=-191.2727$

$\mathbf{p}>\boldsymbol{Z}$

$95 \%$ conf Interval

Employee performance Coefficient Std.error $Z$

\begin{tabular}{|c|c|c|c|c|c|c|}
\hline Control environment & 0.6178474 & 0.2872821 & 2.15 & 0.032 & 0.0547847 & 1.18091 \\
\hline Risk assessment & -0.2721134 & 0.2741517 & -0.99 & 0.321 & -0.8094408 & 0.266214 \\
\hline Control activities & -0.0588757 & 0.278488 & -0.21 & 0.833 & -0.6047021 & 0.4869507 \\
\hline $\begin{array}{l}\text { Information } \\
\text { communication }\end{array}$ & 0.0587114 & 0.320724 & 0.18 & 0.855 & -0.569869 & 0.6873189 \\
\hline Monitoring & 0.4789871 & 0.271493 & 1.76 & 0.078 & -0.0531295 & 1.011104 \\
\hline /cut1 & 2.371214 & 2.545217 & & & -2.617321 & 7.359748 \\
\hline /cut2 & 4.874413 & 2.568616 & & & -0.1599818 & 9.908808 \\
\hline
\end{tabular}

\section{Discussion}

This study examined the effect of internal control system on employee performance of small scale manufacturing enterprises in Ondo State. It considered how control environment, risk assessment, control activities, information and communication and monitoring significantly influence employees timely completion of work, employees doing their work properly, employees punctuality to work and employees loyalty to the organisation. The ordered logistic regression revealed that internal control system had a positive significant effect on employee performance.

The findings support the result from a similar study that was conducted earlier to explore the degree of implementation of COSO internal controls in small organizations (Mutnuru, 2016). He found a significant positive relationship between internal controls implementation and employee engagement. All COSO control components when implemented are relevant to employee performance (Almakhadmeh, 2014). The weak implementation of any component 
may render other components ineffective. This is the reason why all aspects of internal control are implemented for efficiency and effectiveness of organisational activities and employees. It could be that the moderate implementation of information and communication as well as monitoring in the sampled enterprises might have accounted for the little extent of employees doing their work properly, employees punctuality to work and employees loyalty to the organisation.

Another finding of this study is that internal control has a significant effect on employee performance of small scale manufacturing enterprises. Almakhadmeh (2014) found that internal control systems have influence on employee performance. Using analytical methodology, the researcher established a positive relationship between internal control and staff performance. Internal control adds value to employee job performance where a well controlled organisation enhances job security and protects the resources of organisations which may improve organisational productivity and profitability. In their findings, Ewa and Udoayang (2012) showed that a strong internal control system prevents employees from committing fraud while a weak one is an invitation to its commission. It follows that when the control system is effective, employee performance itself will be measurable and monitored. In such a situation, fraudulent activities such as theft, graft, embezzlement and insider abuse are easily detected and corrected.

The finding is similar to the result of the study that was conducted in Edweso General Public Hospital, Ghana which found internal control system being positively related to employee satisfaction (Osei-Boakye, 2016). Although the study was on employee satisfaction, it could be deduced that a satisfied employee would perform well on the job. The findings of the study support Linval (2012) that internal control has positive effects on small restaurants' survivability and profitability. It agrees with Mwakimasinde, Odhiambo and John (2014) that internal control system helps increase performance of sugarcane outgrowers in Kenya. The finding is different from the result of Goodwin-Stewart and Kent (2006) that internal control system is positively related with firm size and commitment to risk management but weakly associated with corporate management. The implication of these results is that internal control needs to be put in place and implemented in small scale manufacturing organisations so that business failures occasioned by employee related lapses can be eliminated or minimised.

\section{Conclusion}

Internal control system is important for the smooth running of an organisation. There are financial and non-financial assets that need to be efficiently and effectively controlled and monitored so that the organisation can remain profitable and evergreen. The study has shown that internal control system influences employee performance of the selected small scale manufacturing enterprises. It is therefore necessary that owners of small businesses invest in internal control system instead of emphasising cost reduction to the detriment of thier enterprises and ensure that employees are punctual and keep their loyalty to their employers. On this, internal control system should be strengthened to prevent asset loss and employee indifference to the achievement of organisational objectives. Small scale manufacturing enterprises should focus more on the control environment, information and communication and monitoring components of internal control system as they will aid employee performance. 


\section{MInstitute Macrothink $_{\text {Int }}$}

This study has contributed to the body of knowledge in the area of internal control and employee performance.

\section{Limitations}

This study was carried out on small scale manufacturing enterprises generally. Since there are different production cycles and products which may present different control challenges, the study can be replicated in some specific manufacturing outfits. Also, limitation might be linked to a dearth of literature on internal control and employee performance even though it is an important area in management and accounting. Most studies focus on internal control and financial performance or organisational performance whereas competent employees signify effectiveness of internal control system. Employees may make or mar organisational success depending on their level of quality and commitment.

The study examined the COSO internal control system and perceived employee performance. Business owners alone rated the perceived employee performance which could have been subjective. Further research should be conducted to cover other areas of employee performance.

\section{References}

Aboazoum, H. M. E., Nimran U., \& Mosadieq M. A. (2015). Analysis factors affecting employees' job performance in Libya. Journal of Business and Management, 17(7), $42-49$

Adagye, I. D. (2015). Effective internal control system in the Nasarawa State tertiary educational institutions for efficiency: A case of Nasarawa State Polytechnic, Lafia. International Journal of Social, Behavioural, Educational, Economic, Business and Industrial Engineering, 9(11), 3704-3709

American Institute of Certified Public Accountants (AICPA). (2007). Statement on auditing procedure No.48. New York, N.Y: Author.

Arindam, N. (2016). 16 Factors that lead to poor performance at the workplace. Retrieved from

http://www.commlabindia.com/resources/training-guides/improve-performance-through-proc ess-training.php.15/10/2017

Avolio, B. J. (2007). Promoting more integrative strategies for leadership theory-building. American Psychologist, 62(1)25-33. https://doi.org/10.1037/0003-066X.62.1.25

Braun, G. (2016). Control Hepatitis: Online Article. Retrieved from www.losangelescentralcoast2bcfo.com

Campbell, S., \& Hartcher, J. (2003). Internal control for small business. Certified Public Accountant, Australia. Retrieved from www.cpaaustralia.com.au

Committee of Sponsoring Organizations of the Treadway Commission (COSO). (1992). Internal control-integrated framework (2) New York, NY: Author.

Committee of Sponsoring Organizations of the Treadway Commission (COSO). (1994). Internal control-integrated framework (3) New York, NY: Author.

Dapper, E. M. (2013). Personnel outsourcing and corporate performance. European Journal of Business and Management, 5(26), 150-155.

Dunmade, E. O., \& Aderibigbe, A. S. (2017). The nexus between employee's motivation and 
organizational performance in some selected banks in Akure Metropolis. International Journal of Social Sciences and Conflict Management, 2(4), 1-24.

Ewa, E. U., \& Udoayang, J. O. (2012). The impact of internal control design on banks' ability to investigate staff fraud, and life style and fraud detection in Nigeria. International Journal of Research in Economics \& Social Sciences, 2 (2), 32-43.

Goodwin-Stewart, J., \& Kent, P. (2006). The use of internal audit by Australian companies. Managerial Auditing Journal, 21(1), 8-101. https://doi.org/10.1108/02686900610634775

Kamau, C. N. (2013). Effect of internal controls on the financial performance of manufacturing firms in Kenya. (Unpublished master's thesis) University of Kenya.

Leviticus, J. (2018). The most important factors when judging staff performance: Online article retrieved from www.smallbusiness.chron.com

Linval, F. (2012). The effect of internal control on the operating activities of small restaurants in Australia. Journal of Business \& Economics Research, 10(6), 361-374. https://doi.org/10.19030/jber.v10i6.7027

Mc Gregor, (1960). The human side of enterprise (1st ed.). McGraw Hill, New York.

Modisane, R. (2013). The challenges facing development of SMMEs small in Botswana.

Gaborone: Stanbic Bank of Botswana. Retrieved from www.stanbicbank.co.bw

Muogbo, U.S. (2013). The influence of motivation on employees performane: A study of some selected firms in Anambra State. An International Journal of Arts and Humanities Bahir Dar, Ethiopia, 2(3), 134-151.

Mwakimasinde, M., Odhiambo, A., \& John B. (2014). Effects of internal control systems on financial performance of sugarcane outgrower companies in Kenya. IOSR Journal of Business and Management, 16(12), 62-73.

Ndifon, E., \& Patrick, E. (2014). The impact of internal control activities on financial performance of tertiary institutions in Nigeria. Journal of Economics and Sustainable Development, 5(16),156-165.

Nigerian Association of Small Scale Industrialists (NASSI). (2016). Data base.

Noe, R. A., Hollenbeck, J. R., Gerhart, B., \& Wright, P. M. (2011). Fundamentals of human resource management (4th ed.). New York: McGraw-Hill Irwin

Oseifuah, E. K., \& Gyekye, A. B. (2013). Internal control in small and microenterprises in the Vhembe District, Limpopo Province South Africa. European Scientific Journal, 9(4) 241-251.

Olatunji, T. E. (2013). The impact of accounting system on the performance of small and medium enterprises in Nigeria. International Journal of Business and Management Invention, 2(9), 13-17.

Rashid, S., Shireen, M., Rab, N. L., Anam, I., Hafiza, H. N., \& Somia, Y. (2013). Factors affecting the performance of employees at work place in the banking sector of Pakistan. Middle-East Journal of Scientific Research, 17(9), 1200-1208.

Sager, K. L. (2008). An exploratory study of the relationship between theory $\mathrm{X} / \mathrm{Y}$ assumptions and superior communicator style. Mnagement Communication Quarterly, 22(2), 288-312. https://doi.org/10.1177/0893318908323148 
Sorenson, P. (2015). Theory X and Theory Y. Management. https://doi.org/10.1093/obo/9780199846740-0078

Stevenson, W. J. (2006). Production, operations management (6th ed.). New York: Mc Graw Hi.11 Irwin.

Tumisang, S., \& Swami B. N. (2014). Impact of internal controls in managing resources of small business: Case study of Botswana. Journal of small business and entrepreneurship development, 2(2), 87-105.

Wallgren, L. G. (2013). Theory Y embedded in Theory X: The limited role of autonomy in decreasing perceived stress among IT consultants. International Journal of Human Capital and Information Technology Professionals, $4(4), \quad$ 1-17. https://doi.org/10.4018/ijhcitp.2013100101

Yamane, T. (1967). Statistics, An introductory analysis (2nd ed.). New York: Harper and Row.

\section{Copyright Disclaimer}

Copyright for this article is retained by the author(s), with first publication rights granted to the journal.

This is an open-access article distributed under the terms and conditions of the Creative Commons Attribution license (http://creativecommons.org/licenses/by/3.0/). 